Jamison suggests that manic-depressive illness is in fact the expression of "malfunctions in a master biological clock". Her studies show pronounced seasonal patterns in productivity among writers and artists, confirmed by the biographies of many outstanding ones (Schumann composed over 130 songs in one year). It is quite likely that these creative periods coincide with swings of mood - particularly upwards - and that these in turn may coincide with seasonal changes in natural light.

If Jamison's general thesis is true, serious philosophical and ethical issues are involved, particularly now that better treatments are available for affective disorder. Most sufferers seek treatment today, even if it may dampen down their creativity, but those in the past, of course, had no such choice open to them. Jamison deals with the complex scientific issues in a vivid and readily intelligible way, only marred by occasional descent into Time-Life language and some diagnostic imperialism in assuming that the US system is the only one worth mentioning. These are minor blemishes, though, in an important work that should provoke some serious rethinking in several corners of academe.

Hugh Freeman is editor of the British Journal of Psychiatry, 17 Belgrave Square, London SW1X 8PG, UK.

\section{Our world in collision}

\section{Reinald Schröder}

Universal Ice: Science and Ideology in the Nazi State. By Robert Bowen. Belhaven: 1993. Pp. 189. £39.50. (US dist., St Martin's Press.)

NOWADAYS the name of Hörbiger evokes only the celebrated Viennese theatrical dynasty, especially its founders, the brothers Paul and Attila. It is less likely to bring to mind their father, Hanns, and his "World Ice Doctrine". Not so in Germany 50 years ago.

Robert Bowen, a geologist who concluded his academic training in Münster in 1991, has sought to rescue Hörbiger's cosmogony from oblivion, and in particular to discover how it was that this abstruse farrago of pseudoscience found so many adherents in the Third Reich, reaching indeed to the uppermost pinnacles of power. For they included Adolf Hitler and above all Heinrich Himmler.

Hanns Hörbiger (1860-1931) was a successful Austrian engineer, to whom the World Ice Doctrine came, late in the nineteenth century, "in bitter anguish of the spirit, as a vision"; its "cosmic, fathomless depths" threw his body into "feverish, shuddering spasms". Out of this experience Hörbiger drew his theory, which linked terrestrial and cosmic processes in a unifying drama of nature. In 1913, working with the amateur astronomer Philipp Fauth, he set down his cogitations in a book entitled Hörbiger's Glacial Cosmogony. Bowen's heroic endeavour has been to assimilate this barely readable work, comprising close on 800 pages of impenetrable gibberish, and boil down its message to a few dozen comprehensible pages. He has avoided unfair selectivity without sacrificing the perspective of a trained scientist.

According to Hörbiger then, the Mil- ky Way is made up of fragments of ice that lie outside the gravitational field of the Sun. When this veil of ice passes into the domain of the planetary system, it plunges into the Sun, melts and evaporates. Immense exploding funnels - the sunspots - eject mighty fountains of steam - the solar prominences - which instantly freeze to ice powder; this showers down on the inner planets, which thus acquire a thick glacial crust. The Moon itself has a coat of ice several kilometres thick. In the Earth's atmosphere the ice dust melts into rain, while larger lumps (meteors) burst and strike the Earth as hailstorms.

But it is not only ice that descends on the Sun and planets. The allencompassing ether slows the movement of all the heavenly bodies until they are trapped by the gravitational pull of the nearest inner planet and become moons, later to be absorbed by their planet. The planets are gradually approaching the Sun in spiral trajectories and will finally be drawn in and consumed. Our own planet too once possessed other moons, which crashed into the Earth, thus provoking natural catastrophes such as the immersion of Atlantis and Noah's Flood.

It is not surprising that a theory that scorns so many established facts and rests confessedly on nothing more than intuition and myth was rejected, or worse ignored, by the world of science. Hörbiger saw himself indeed in the line of Julius Robert Mayer, discoverer of conservation of energy, another unrecognized genius.

After this promising start, Bowen's book is a sad disappointment, for it tells us nothing new about the part played by the World Ice Doctrine in the history of the Third Reich. Readers have first to fight their way through a rather disjointed potpourri of German intellectual history in the 1920s and '30s. From Nietzsche on Wagner, the Mormons and the "Nazi philosopher" Heidegger, the text moves on to the campaign by the "Aryan physicists" (Lenard and Stark) against "Jewish physics" (quantum theory and relativity). The relation of all this to the World Ice Doctrine is left obscure; errors of fact accumulate (Fritz Strassmann, who worked with Otto Hahn on the discovery of nuclear fission, for instance, is given a posthumous Nobel prize), and standard works on the history of science in Germany at that time have not been cited, or, it seems, even consulted.

Nor do we learn how Hörbiger's theory influenced the Nazis. There are only a few pages in which it is related in detail that in 1937 a certain von Elmayer-Vestenbrugg, writing in a volume of the Kampfschriften der Obersten SA-Führung (Books of Struggle of the SA High Command) broke a lance for the World Ice Doctrine, commending this Nordic concept of the origins of the world and of natural catastrophes, so shamefully disregarded by the academics, as an appropriate Nazi ideol-

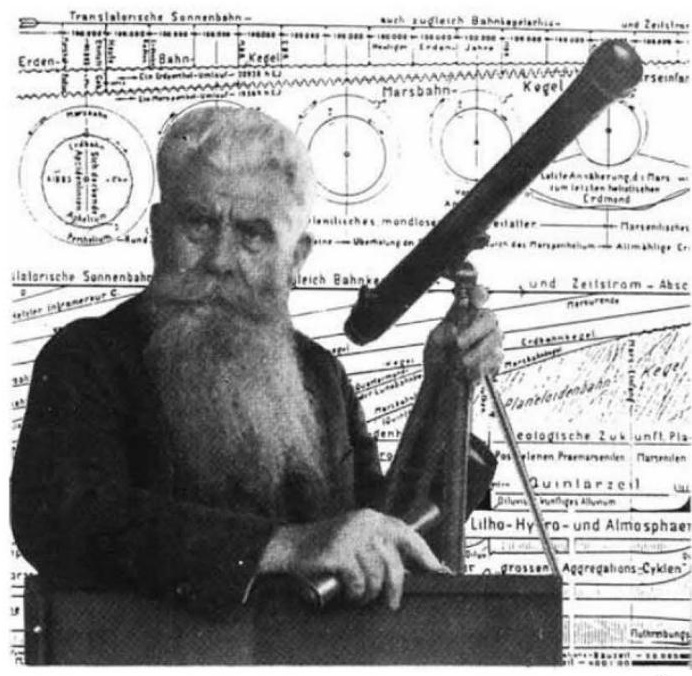

Hörblger and detall from his Glacial-Kosmogonie

ogy. Here Bowen unjustly accuses Hörbiger of embracing the ideology of the Nordic master race, for which there is no evidence in his writings. Neither does he reveal whether the SA author's article met with a favourable reception, or which members of the Nazi leadership declared for Hörbiger in consequence.

There is contradictory evidence in the literature as to whether Hitler was a follower of Hörbiger. It is certain only that he did not exert himself to promote the dissemination of Hörbiger's ideas. For Reichsführer SS Himmler, it was quite another matter: the studies of Brigitte Nagel (Die Welteislehre: Ihre Geschichte und ihre Rolle im "Dritten Reich", GNT, 1991) have exposed him as the highest-ranking supporter of the 
World Ice Doctrine. He began a search for conclusive evidence in the SS "Research Institute" ("Ahnenerbe", or "Ancestral Heritage"), with a view to elevating the doctrine to official Nazi ideology.

It is true that Himmler was not deflected from his faith in the World Ice Doctrine by the vehement opposition of the academic establishment, the "journeymen of science", for whom he harboured a deep loathing. This is certainly to be inferred from his harsh treatment of opponents of the Hörbiger ideology in his own ambit. But he was compelled to give the impression of distancing himself from the World Ice Doctrine, and even the journals under his control were deterred from running advertisements for new books about the theory. The research groups in the Ancestral Heritage were renamed and were able to pursue their researches only covertly.

This fiasco resulted primarily from the activities of the physicist and Nobel laureate - and ardent admirer of Hitler - Philipp Lenard, who vigorously fought the World Ice Doctrine as "Volksverdummung" — dulling of the people's mind. One may then hazard the interpretation that Himmler sought to protect Werner Heisenberg - who had been libellously dubbed "the Ossietzky of physics" by Johannes Stark, Lenard's spiritual patron, in the Schwarze Korps, the journal of the SS - as a means of striking at his arch-enemy in the propagation of the World Ice Doctrine, Lenard, whom he did not dare to challenge in matters of science.

Bowen is seemingly unacquainted with the state of knowledge in this area, for he finally goes so far as to say that "Hörbiger might well have become a scientific overlord in Nazi Germany probably more important than was Trofim D. Lysenko in Stalin's Soviet Union". In fact, even if Hörbiger had been alive, the World Ice Doctrine would never have achieved the standing of an official Nazi ideology. Such an outcome was not even attained by Lenard's "Aryan physics". In the course of the war the pragmatic professionals gained the upper hand over the pure Nazi ideologues in all important matters relating to military technology, and thus furthered the implementation of Hitler's destructive mania. And Hitler's paranoid hatred of the Jews did not stem from the World Ice Doctrine, but rather from the racial theories thrown up by social Darwinism at the turn of the century.

Reinald Schröder is at Vaihinger Strasse 37, 7000 Stuttgart 80, Germany.

Nature thanks Walter Gratzer for translating this review from the German.

\section{Invisible Johnny}

\section{Ray Monk}

John von Neumann. By Norman Macrae. Pantheon: 1992. Pp. 405. \$25.

DURING his all-too-brief life (he was 53 when he died), John von Neumann was regarded by many, including both prominent politicians and Nobel-prizewinning scientists, as the most intelligent person in the world. That he is not better known among the general public is prob-

\section{IMAGE UNAVAILABLE FOR COPYRIGHT REASONS}

\section{John von Neumann with his wlfe, Klara, and pet dog Inverse (1954).}

ably due to the fact that, unlike say Einstein or Freud, his name is not associated with a single revolutionary breakthrough in any one discipline. His fame is, rather, diffused throughout the astonishingly varied fields of his interests. Mathematical logicians know him as the man who, in the 1920 s, provided one of the first systems of axioms for set theory; in theoretical physics he is known as the mathematician who gave precise form, in a wellknown book of 1932 , to the so-called 'Copenhagen interpretation' of quantum mechanics; social scientists will have come across his name as one of the joint authors, together with Oskar Morgenstern, of the classic work of game theory; historians of the Cold War will know him as the technical expert responsible for advising first Truman and then Eisenhower on the strategy of 'maximum retaliation'; while computer scientists - and, increasingly, the general public - will recognize his name in connection with the 'von Neumann architecture' that lies at the heart of all modern computers.

Like that of those other great mathematical logicians, Kurt Gödel and Alan Turing, von Neumann's role in shaping the development of the twentieth century was, until recently, known to only a few. Public awareness of the other two, however, has been massively increased by the publication of two widely read books: Douglas Hofstadter's astonishing bestseller Gödel, Escher, Bach (Basic Books/Penguin, 1980) and Andrew Hodges's superb biography Alan Turing: \& The Enigma of Intelligence Hutchinson, 1984). The success of these two books, both of them rich in scholarship and exciting to read, should have paved the way for a study of von Neumann that was lively enough to excite, and well-informed enough to satisfy, the curiosity of a wide audience about the nature and the importance of his achievements. Sadly, this is not that study.

Norman Macrae is a former editor of The Economist. He writes in a style that, while accessible, is perhaps too breezy for his subject matter. Von Neumann is called "Johnny" throughout the book, which is bad enough, but worse is Macrae's habit of putting an adjective in front of this familiarized form of his subject's name and referring to him as, for example, "cherubic Johnny", "inexperienced Johnny," "Computer Johnny", "logical Johnny" and, towards the end of von Neumann's life, "overweight Johnny" (although, thank God, he spares us "cancerous Johnny"). Breezy Norm, one feels, does not read his work aloud. How else can one explain his letting go unrevised a phrase like: "the appearance of Johnnies is the cheapest way of increasing man's material prosperity very fast"?

Even worse than these stylistic infelicities, however, is the fact that Macrae does not seem very interested in mathematical logic. His work is therefore uncertain and unreliable at precisely the point when it should be laying an intelligible and enlightening foundation for what is to follow. For, as with Alan Turing, von Neumann's later multifarious activities were all in some way grounded in his early work in logic.

Indeed, one feels throughout the early sections of the book that Macrae is just dying to get on to what he is really interested in: von Neumann's work on economics, computers and nuclear deterrence during and immediately after 